\title{
UVB-induced premature senescence of human diploid skin fibroblasts
}

\author{
Florence Chainiaux, Joao-Pedro Magalhaes, François Eliaers, \\ José Remacle, Olivier Toussaint* \\ Laboratory of Cellular Biochemistry and Biology, Department of Biology, University of Namur (FUNDP), \\ Rue de Bruxelles 61, B-5000 Namur, Belgium
}

Received 6 December 2001; received in revised form 20 January 2002; accepted 30 January 2002

\begin{abstract}
In this work, we show that repeated stresses with UVB $(290-320 \mathrm{~nm})$ induce stress-induced premature senescence (SIPS) of skin human diploid fibroblasts (HDFs). HDFs at early cumulative population doublings were exposed three or five times to increasing subcytotoxic doses of UVB with one stress per day. After 2 days of recovery, several biomarkers of replicative senescence were established. First, there was an increase in the proportion of cells positive for senescence-associated $\beta$-galactosidase activity. Second, there was a loss of replicative potential as assessed by a very low level of $\left[{ }^{3} \mathrm{H}\right]$-thymidine incorporation. Third, the steady-state level of the mRNA of three senescence-associated genes, i.e. fibronectin, osteonectin and SM22, was increased in HDFs at $72 \mathrm{~h}$ after three and five exposures to UVB. In conclusion, these results suggest that it is possible to induce SIPS in HDFs after repeated exposures to subcytotoxic doses of UVB. This model could be used to test whether HDFs in UVB-induced premature senescence are able to promote epithelial cell growth and tumorigenesis in skin, as shown recently with HDFs in $\mathrm{H}_{2} \mathrm{O}_{2}$-induced premature senescence.
\end{abstract}

(C) 2002 Elsevier Science Ltd. All rights reserved.

Keywords: UVB; Stress-induced premature senescence; Fibroblasts; Tumorigenesis

\section{Introduction}

Senescence of replicative cells can be defined as irreversible growth arrest (replicative senescence) due either to telomere shortening linked with the DNA end-replication problem, overexpression of certain oncogenes or tumor suppressors, or stress-induced premature senescence (SIPS) after exposure to a variety of oxidative stresses and DNA damaging agents (for a review, see [1]). Examples of biomark-

\footnotetext{
* Corresponding author. Tel.: +32-81-724132; fax: +32-81-724135.

E-mail address: olivier.toussaint@fundp.ac.be (O. Toussaint).
}

ers of senescence of normal human diploid fibroblasts (HDFs) which appear at a long term after exposure to conditions like tert-butylhydroperoxide ( $t$-BHP), $\mathrm{H}_{2} \mathrm{O}_{2}$, hyperoxia, mitomycin $\mathrm{C}$, hydroxyurea, 5-bromodeoxyuridine include senescence-like morphology, decrease in the maximum number of in vitro cumulative population doublings (CPDs), irreversible growth arrest in $\mathrm{G} 1$, senescence-associated $\beta$-galactosidase activity (SA $\beta$-gal), accelerated telomeres shortening, lipofuscin accumulation and change in expression level of many genes (for a review, see [2]).

Skin is exposed to UVB and UVA. UVB (290-320 $\mathrm{nm})$ and UVA (320-400 nm) are essential components 
of sunlight that generate severe oxidative stress in the skin. UVB crosses the epidermis and reaches the upper dermis [3]. The UVB interact with cellular chromotophores and photosensitizers, resulting in the generation of reactive oxygen species (ROS), DNA damage (e.g. pyrimidine dimers) and activation of cytoplasmic signal transduction pathways that are related to growth, differentiation, replicative senescence and connective tissue degradation [4]. The biological responses to UV can be immediate and transient (inflammation, sunburn cell formation, pruritus) or delayed and chronic (photoaging, immunosuppression, photocarcinogenesis) [5].

The aim of this study was to develop a model of UVB-induced premature senescence using subcytotoxic doses of UVB. We show that repeated exposure of skin HDFs to subcytotoxic doses of UVB lead to the long-term appearance of several biomarkers of senescence such as senescence associated $\beta$-galactosidase activity, a sharp decrease in the DNA synthesis capability and overexpression of several genes known to be overexpressed in senescent HDFs.

\section{Materials and methods}

\subsection{Cell culture}

AG04431 skin HDFs were obtained from the Coriell Institute for Medical Research (USA). HDFs were routinely cultivated in $75 \mathrm{~cm}^{2}$ flasks (Cel Cult, UK) containing $15 \mathrm{ml}$ of basal medium eagle (BME) (Gibco-BRL, UK) supplemented with $10 \%$ fetal calf serum (FCS) (Flow Laboratories, UK) and $2 \mathrm{mM}$ L-glutamine, $100 \mathrm{U} / \mathrm{ml}$ penicillin and $100 \mu \mathrm{g} / \mathrm{ml} \mathrm{strep-}$ tomycin. Cultures were grown at $37^{\circ} \mathrm{C}$ in an atmosphere containing $5 \% \mathrm{CO}_{2}$. When confluent, cells were subcultivated until they reached irreversible growth arrest, that is replicative senescence, as previously described [6].

\subsection{UVB light exposure}

Cultures of HDFs at early CPDs were submitted to repeated UVB stress. HDFs were washed once with PBS and exposed to UVB radiation in a thin layer of phosphate buffer saline $\mathrm{pH} 7.4,10 \mathrm{mM}$ phosphate (PBS) using three Philips TL 20W/01 lamps (Philips,
The Netherlands) at day 3 after subcultivation at 10,000 cells $/ \mathrm{cm}^{2}$, which represented half-confluence. These lamps emit mainly UVB, peaking at $311 \mathrm{~nm}$. Radiation was carried out at room temperature at a target distance of $30 \mathrm{~cm}$. The emitted radiation was checked using a UVR-radiometer with a UVB-sensor (Bioblock Scientific, Belgium). After radiation, the PBS was replaced with BME containing $1 \%$ FCS in order not to interfere with the LDH cytotoxicity assays which were achieved preliminarily to the protein assay and cell counting. Control samples were submitted to the same conditions without UVB illumination. HDFs were submitted to a repeated subcytotoxic exposure to UVB stress with one stress per day for 3 or 5 days.

\subsection{Cytotoxicity assays}

At $48 \mathrm{~h}$ after the last stress, cells were washed twice with PBS and lysed with $\mathrm{NaOH} 0.5 \mathrm{~N}$. The protein content of the samples was assayed by the Folin method described by Lowry et al. [7]. Triplicates were always performed. The results are expressed as mean \pm S.D.

\subsection{Senescence-associated $\beta$-galactosidase (SA $\beta$-gal) activity}

At $48 \mathrm{~h}$ after the last stress, cells were trypsinised and seeded in squared $35 \mathrm{~mm}$ culture dishes (Falcon, UK) containing $2 \mathrm{ml}$ of BME and $1 \%$ FCS at a density of 700 cells per $\mathrm{cm}^{2}$. At $24 \mathrm{~h}$ after, SA $\beta$-gal activity was determined as described by Dimri et al. [8]. The population of SA $\beta$-gal positive cells was determined by counting 400 cells per dish. The proportions of cells positive for SA $\beta$-gal activity are given as percentage of the total number of cells counted in each dish. Triplicates were always performed. The results are expressed as mean \pm S.D.

\subsection{Measurement of DNA synthesis}

At $24 \mathrm{~h}$ after the last stress, cells were seeded in 24 well plates (Cel Cult, UK) at a density of 10,000 cells/well. A $1 \mu \mathrm{Ci}\left[{ }^{3} \mathrm{H}\right]$-thymidine (specific activity: $2 \mathrm{Ci} / \mathrm{mmol}$, Du Pont NEN, USA) was added to BME $+1 \%$ FCS for $48 \mathrm{~h}$. Cells were washed twice with PBS, fixed 5 min with trichloroacetic acid (TCA), washed once with $70 \%$ ethanol and once with PBS. 
Table 1

Primers used for semi-quantitative RT-PCR

\begin{tabular}{lcl}
\hline Gene & $\begin{array}{l}\text { Position } \\
\text { (bp) }\end{array}$ & Sequence \\
\hline Fibronectin & $4834-4856$ & $5^{\prime}$-ggc att cac tga tgt gga tgt cg-3' \\
& $5247-5269$ & $5^{\prime}$-cat aag tcc tga tac aac cac gg-3' \\
Osteonectin & $63-84$ & $5^{\prime}$-ggc ctg gat ctt ctt tct cct t-3' \\
& $412-434$ & $5^{\prime}$-aag aag tgg cag gaa gag tcg aa-3' \\
SM22 & $249-266$ & $5^{\prime}$-tgg cgt gat tct gag caa-3' \\
& $470-487$ & $5^{\prime}$-ctg cca agc tgc cca agg-3' \\
23 kDa HBP & $280-300$ & $5^{\prime}$-tgc ccc aca aaa cca agc gag-3' \\
& $614-634$ & $5^{\prime}$-tgg gct cag acc agg agt ccg-3' \\
\hline
\end{tabular}

$\mathrm{NaOH} 0.5 \mathrm{~N}$ was added for $30 \mathrm{~min}$ and neutralized by $\mathrm{HCl} 0.5 \mathrm{~N}$. The incorporated radioactivity was quantified by a scintillation counter (Beckman Coulter Inc., USA). Triplicates were always performed. The results are expressed as mean \pm S.D.

\subsection{Semi-quantitative RT-PCR}

Total RNA was extracted (total RNA extraction kit, Promega, USA) $72 \mathrm{~h}$ after the last stress. Semi-quantitative RT-PCRs were achieved in the exponential linear zone of amplification for each gene studied in one step (access RT-PCR kit, Promega, USA). In presence of $\left[\alpha^{32} \mathrm{P}\right]$ dideoxycytosine $(0.025 \mu \mathrm{Ci}$ per reaction). RT-PCR were performed using 50 ng RNA, $5 \mathrm{U}$ AMV reverse transcriptase, $5 \mathrm{U}$ Teflon polymerase, $200 \mu \mathrm{M}$ dNTPs, $1 \mathrm{mM} \mathrm{MgSO}_{4}$ and 50 pmol of each primer. The primers are listed in Table 1. After a reverse transcription step of $45 \mathrm{~min}$ at $48{ }^{\circ} \mathrm{C}$, the following PCR cycles were used: denaturation, $94^{\circ} \mathrm{C}, 30 \mathrm{~s}$; annealing, $60^{\circ} \mathrm{C}, 30 \mathrm{~s}$ (except for SM22: $53^{\circ} \mathrm{C}, 30 \mathrm{~s}$ ); elongation, $68^{\circ} \mathrm{C}, 30 \mathrm{~s}$. The number of cycles necessary to be in the exponential zone of the PCR was determined and was 20 cycles for fibronectin, 24 cycles for osteonectin and SM22 and 22 cycles for $23 \mathrm{kDa}$ Highly Basic Protein (23 kDa HBP). A $23 \mathrm{kDa}$ HBP mRNA level was used as reference after it was checked it was stable in our conditions. RT-PCR products were electrophoresed on a $5 \%(\mathrm{w} / \mathrm{v})$ polyacrylamide gel and analyzed with an instant imager (Hewlett-Packard, USA). The dried gels were exposed to MP films (Amersham, Belgium). Negative controls were performed without RNA. Triplicates were always performed. The results are expressed as mean \pm S.D.

\section{Results}

\subsection{Cytotoxicity after UV irradiation}

To select the conditions of subcytotoxic stress, cytotoxicity induced by UVB irradiation was measured at $48 \mathrm{~h}$ after three or five repeated exposures to UVB doses ranging from 500 to $1000 \mathrm{~mJ} / \mathrm{cm}^{2}$ (Fig. 1). Cytotoxicity appeared at doses equal to or higher than $750 \mathrm{~mJ} / \mathrm{cm}^{2}$ after three stresses and at doses equal to or higher than $625 \mathrm{~mJ} / \mathrm{cm}^{2}$ after five stresses. Therefore the subcytotoxic doses used throughout this study were $625 \mathrm{~mJ} / \mathrm{cm}^{2}$ for three repeated stresses and $500 \mathrm{~mJ} / \mathrm{cm}^{2}$ for five repeated stresses.

\subsection{Effect of subcytotoxic UVB stresses on the proportion of cells positive for $S A \beta$-gal activity}

SA $\beta$-gal activity was described by Dimri et al. [8]. It was shown to be a reliable biomarker of long-term growth arrest [9]. In our study, the percentage of cells positive for SA $\beta$-gal activity increased with the CPDs. It increased from $10 \%$ of positive cells at $56 \%$ of their proliferative life span to $53 \%$ of positive cells at $90 \%$ of their proliferative life span (Fig. 2). An increase in the proportion of the cells positive for SA $\beta$-gal activity was detectable in HDFs at $56 \%$ of their proliferative life span at $72 \mathrm{~h}$ after UVB exposures. This proportion was around $15 \%$ at $72 \mathrm{~h}$ after three stresses at $625 \mathrm{~mJ} / \mathrm{cm}^{2}$ and $24 \%$ at $72 \mathrm{~h}$ after five stresses at $500 \mathrm{~mJ} / \mathrm{cm}^{2}$.

\subsection{Effect of subcytotoxic UVB stresses on the mitotic index}

The progressive decrease of the proliferation potential followed by irreversible growth arrest is an important feature of replicative senescence. The level of $\left[{ }^{3} \mathrm{H}\right]$-thymidine incorporation was determined at $72 \mathrm{~h}$ after each stress at UVB doses ranging from 375 to $750 \mathrm{~mJ} / \mathrm{cm}^{2}$ in both stress models (Fig. 3). In UVB-stressed cells, sharp dose-dependent decreases of incorporation were found when compared with control cells at the same CPDs. Moreover the higher number of exposures, the lower incorporation level observed. After three exposures to UVB at $625 \mathrm{~mJ} / \mathrm{cm}^{2}$, a quasi-null level of incorporation is still observed at $72 \mathrm{~h}$ after the last stress. This decrease was 


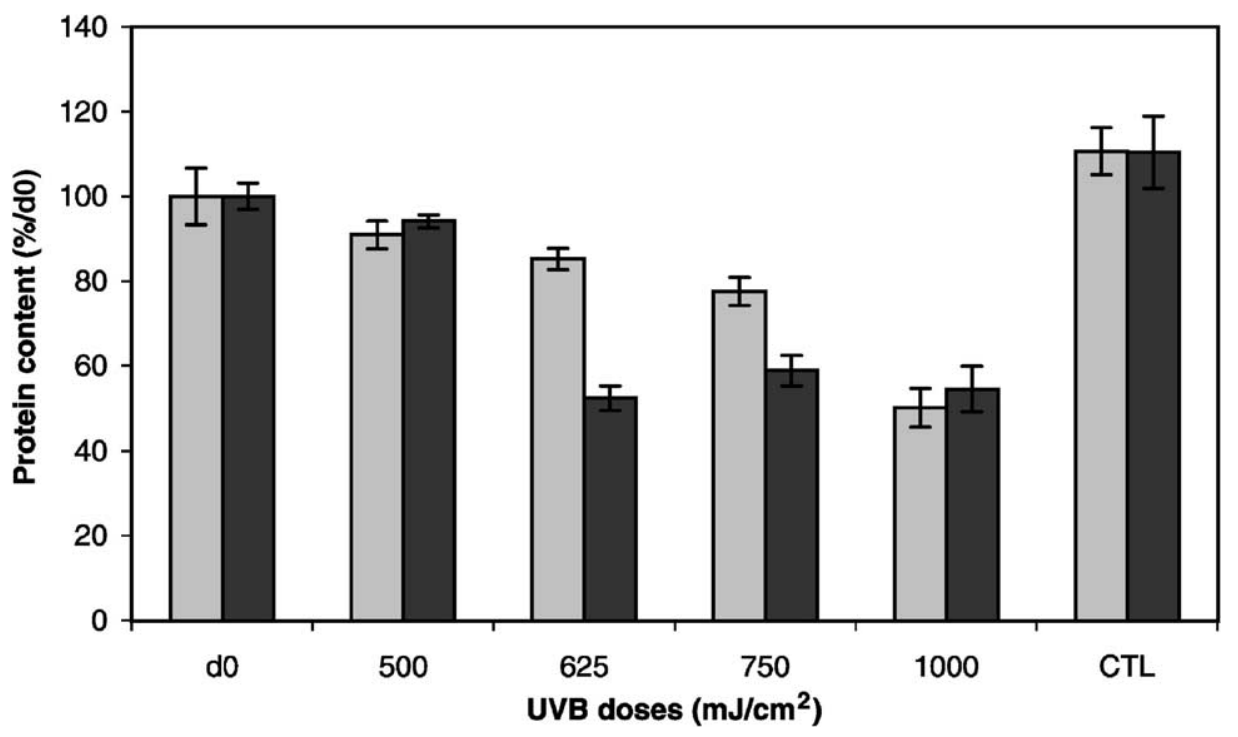

Fig. 1. Cytotoxicity at $48 \mathrm{~h}$ after three or five repeated exposures to UVB. Protein content was determined in HDFs at early CPDs (56\% of their proliferative life span ) to three (grey columns) or five (black columns) repeated UVB stress with one stress per day. Doses ranged from 500 to $1000 \mathrm{~mJ} / \mathrm{cm}^{2}$. The results are expressed as percentage of the values found at day $0(\mathrm{~d} 0)$ before any stress. CTL represents HDFs at early CPDs submitted to the same culture conditions than the stressed cells but without any UVB exposure. The difference between d0 and CTL represented the normal growth of the cells in these conditions. Results are given as mean \pm S.D. from three independent experiments.

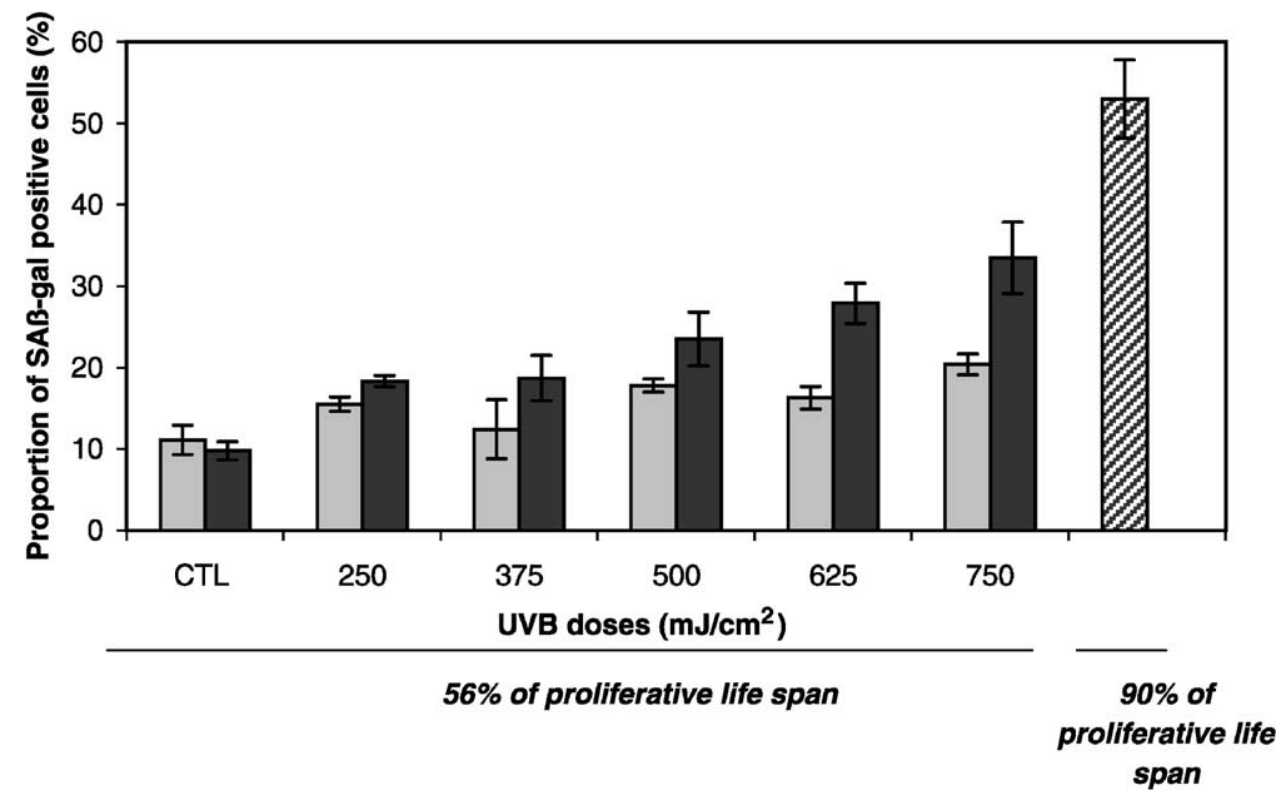

Fig. 2. Effects of repeated UVB stress on the proportion of skin HDFs positive for SA $\beta$-gal activity. Fibroblasts at $56 \%$ of their proliferative life span were exposed to three (grey columns) or five (black columns) repeated UVB stress. CTL represents the control cells submitted to the same culture conditions than the stressed cells but without any UVB exposure. The proportion of SA $\beta$-gal positive cells was also determined for fibroblasts at $90 \%$ of their proliferative life span (dashed column). The results are presented as mean \pm S.D. from three independent experiments. 


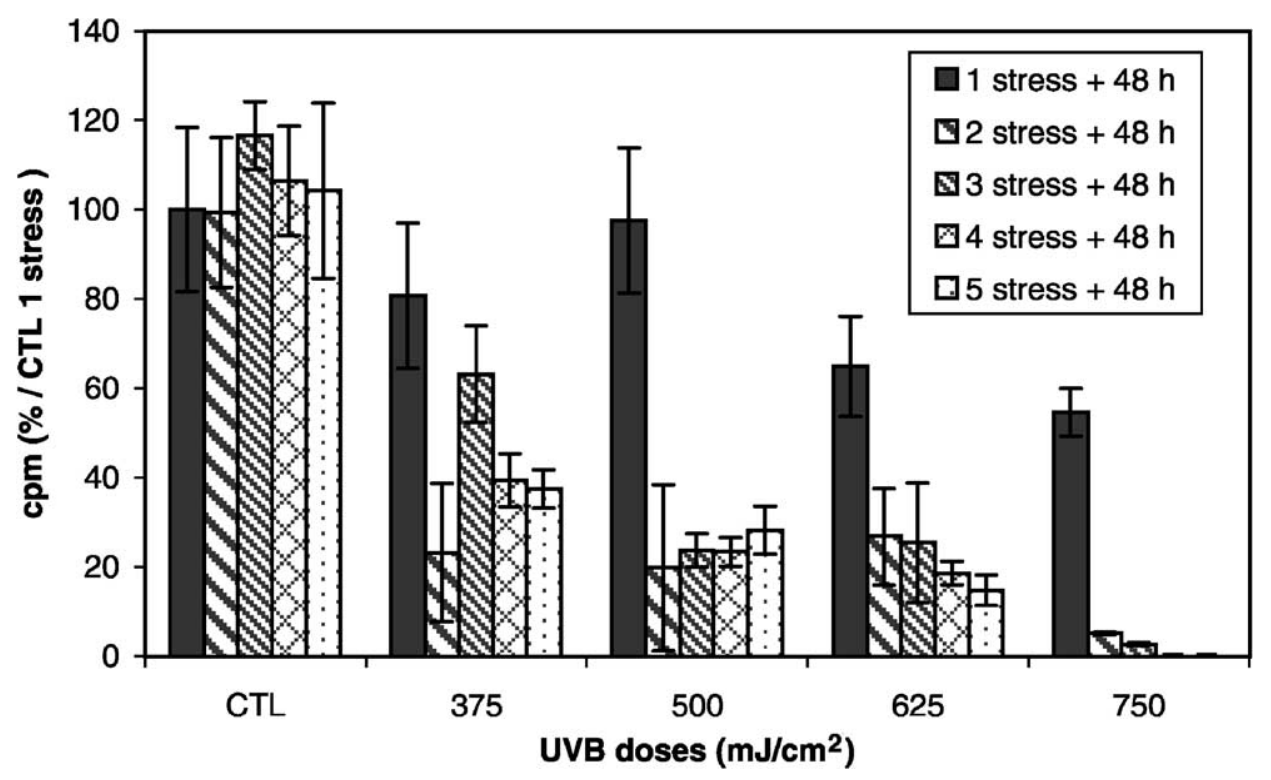

Fig. 3. Estimation of the proliferative potential of skin HDFs repeatedly exposed to UVB by measure of the incorporation of [ $\left.{ }^{3} \mathrm{H}\right]$-thymidine into DNA between days 3 and 7 after stress. The results obtained after one to five stresses were expressed as percentages of the counts per minute (cpm) incorporated by the control cells, which correspond to cells incubated in the same conditions as the stressed cells but without UVB exposure. Other controls obtained at times corresponding to each of the successive stress gave similar values and are also shown. Doses of UVB from 375 to $750 \mathrm{~mJ} / \mathrm{cm}^{2}$ were used in these experiments. The results represent the mean \pm S.D. from three independent experiments.

sharper above this subcytotoxic dose, when the cells were exposed to $750 \mathrm{~mJ} / \mathrm{cm}^{2}$. After five exposures to UVB at $500 \mathrm{~mJ} / \mathrm{cm}^{2}$, there was a dose-dependent and number of stress-dependent dramatic decrease of $\left[{ }^{3} \mathrm{H}\right]$-thymidine incorporation.

\subsection{Gene expression 72 h after repeated subcytotoxic exposure to UVB stress}

It was found previously that fibronectin, osteonectin and SM22 are overexpressed in senescence and in SIPS induced by $\mathrm{H}_{2} \mathrm{O}_{2}$ and $t$-BHP [10]. These genes are also found to be overexpressed when rat fibroblasts immortalized by a temperature permissive SV-40 $\mathrm{T}$ antigen are submitted to heat shock, undergo growth arrest, and display a senescence-like morphology [11]. We studied the steady-state mRNA level of these three genes by semi-quantitative RT-PCR in HDFs at late CPDs ( $>90 \%$ of their proliferative life span) and at $72 \mathrm{~h}$ after three subcytotoxic stresses at $625 \mathrm{~mJ} / \mathrm{cm}^{2}$ and after five subcytotoxic stresses at $500 \mathrm{~mJ} / \mathrm{cm}^{2}$ (Fig. 4).
We used the housekeeping gene coding for the $23 \mathrm{kDa}$ HBP as reference. In skin HDFs at late CPDs (>90\% of their replicative life span), the steady-state mRNA level of fibronectin, osteonectin and SM22 were increased by $2.04-, 1.30-$ and 1.72 -fold, respectively, compared with HDFs at much earlier CPDs (56\% of their replicative life span). After repeated exposures to three UVB stresses at $625 \mathrm{~mJ} / \mathrm{cm}^{2}$, the steady-state mRNA level of these genes underwent a respective increase of 1.56-, 1.86- and 1.65-fold. After five UVB stresses at $500 \mathrm{~mJ} / \mathrm{cm}^{2}$, respective increases of 2.33-, 1.85- and 1.30-fold were observed.

\section{Discussion}

Senescent HDFs, including HDFs in $\mathrm{H}_{2} \mathrm{O}_{2}$-induced SIPS, promote epithelial cell growth and tumorigenesis [12]. Since UVB crosses the epidermis and reaches the upper dermis, it could be possible that HDFs in UVB-induced premature senescence accumulate 


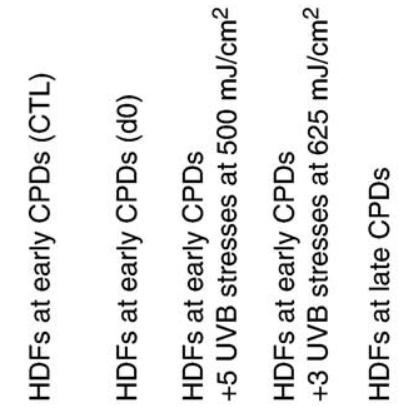

osteonectin

fibronectin

SM22

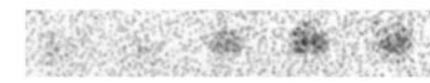

$23 \mathrm{kDa} H B P$

(a)

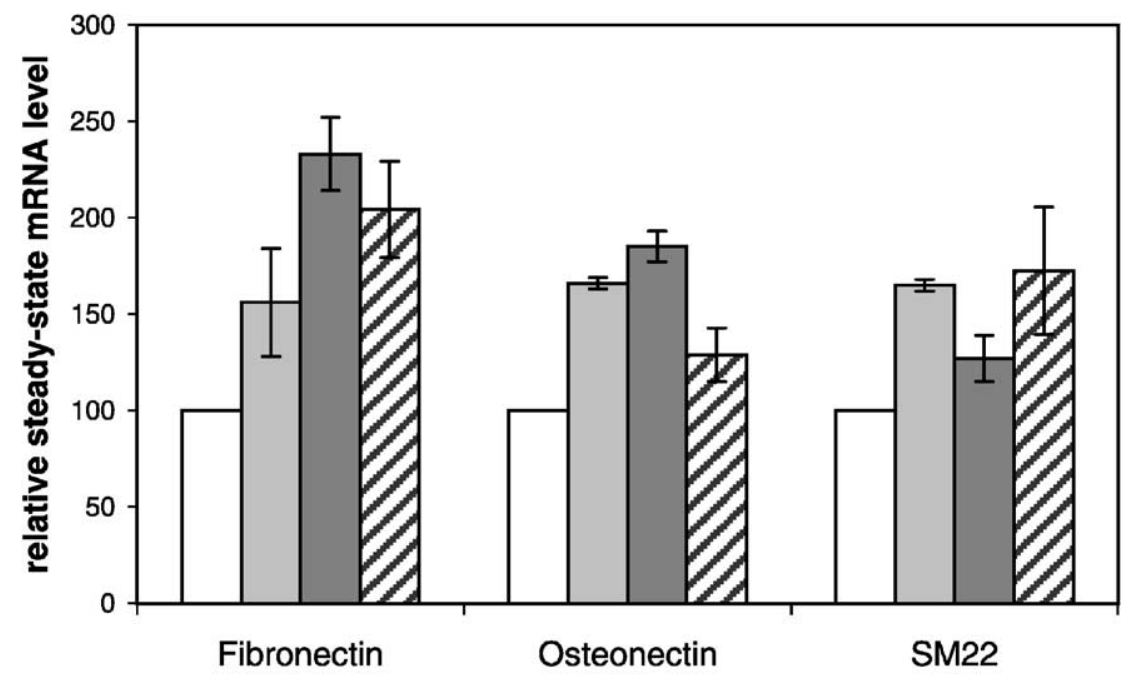

(b)

Fig. 4. Steady-state mRNA level of fibronectin, osteonectin and SM22 $72 \mathrm{~h}$ after three or five repeated subcytotoxic exposures of UVB. (a) Autoradiographs after migration of the products obtained by semi-quantitative RT-PCR performed on fibronectin, osteonectin, and SM22 mRNA with $23 \mathrm{kDa}$ HBP mRNA taken as reference. (b) Quantification of the autoradiographs: HDFs at early CPDs (white columns), HDFs at early CPDs $72 \mathrm{~h}$ after three repeated UVB stress at $625 \mathrm{~mJ} / \mathrm{cm}^{2}$ (grey columns) and five repeated UVB stress at $500 \mathrm{~mJ} / \mathrm{cm}^{2}$ (black columns), and HDFs at late CPDs (dashed columns). A $23 \mathrm{kDa}$ HBP mRNA steady-state level was used as reference since its level was checked to be stable in all conditions tested. The signal obtained for fibronectin, osteonectin and SM22 in non-stressed HDFs at early CPDs is considered as $100 \%$. 
in vivo and promote epithelial cell growth and tumorigenesis. One of the steps before testing this possibility is to develop a model of UVB-induced premature senescence using subcytotoxic doses of UVB. Among the multiple papers which dealt with the effects of UVB on different cell types, very few studies were aimed at the long-term effect of UVB on the appearance of SIPS in HDFs. Earlier studies used UV light but without discriminating the wavelength used and were very descriptive since they were restricted to the description of morphological changes and appearance/disappearance of spots on two-dimensional electrophoreses [13]. Short subcytotoxic oxidative stress protocols have already been used to induce SIPS (for a review, see [2]). Repeated stresses have allowed to decrease very much the dose of stressor [10]. Therefore in this study we developed a model of SIPS where skin HDFs at early passage in culture were exposed to repeated subcytotoxic UVB stress. Up to five stresses were performed, with a stress per day. We considered markers of senescence such as SA $\beta$-gal activity, low $\left[{ }^{3} \mathrm{H}\right]$-thymidine incorporation into DNA and overexpression of senescence-associated genes.

Previous studies have shown that protein assay at $48 \mathrm{~h}$ after stress reflects very well the percentage of surviving cells. In those conditions, this method gave results very similar to those obtained by other methods such as cell counting or assays based on the colorimetric detection of a cellular enzymatic activity [10]. The first step to develop a model of SIPS is always to find doses that are subcytotoxic. Previous works showed it is necessary to consider cell death $48 \mathrm{~h}$ after each repeated subcytotoxic stress to consider total cell death. Indeed, there are cells which apoptosis is triggered within the $24 \mathrm{~h}$ after stress and which will detach from the flasks before $48 \mathrm{~h}$ after stress. From our experience with other types of stress no more cell starts apoptosing from $48 \mathrm{~h}$ after stress [14]. This approach allowed us to determine subcytotoxic doses of UVB after three or five stresses, with a stress per day, these doses being 625 and $500 \mathrm{~mJ} / \mathrm{cm}^{2}$, respectively.

After three stresses, a significant increase in SA $\beta$-gal positive cells was observed at the subcytotoxic dose of $625 \mathrm{~mJ} / \mathrm{cm}^{2}$. This increase was greater at the higher dose of $750 \mathrm{~mJ} / \mathrm{cm}^{2}$. After five stresses at a subcytotoxic dose of $500 \mathrm{~mJ} / \mathrm{cm}^{2}$, the proportion of SA $\beta$-gal positive cells doubled. At $750 \mathrm{~mJ} / \mathrm{cm}^{2}$, this proportion increased by more than three-fold. Similar results were obtained when fœtal lung $\mathrm{HDFs}$ were exposed to subcytotoxic concentrations of $\mathrm{H}_{2} \mathrm{O}_{2}$ [15] or $t$-BHP [10]. According to this criteria, skin HDFs exposed to UVB and fœtal lung HDFs exposed to $\mathrm{H}_{2} \mathrm{O}_{2}$ or to $t$-BHP behave like presenescent cells.

In this study, we also observed a very low level of $\left[{ }^{3} \mathrm{H}\right]$-thymidine incorporation into DNA both in the three- and five-stress models, between days 3 and 7 after the stress. The ratios of incorporation between the cells exposed to repeated stresses or not are very similar to those observed in cells exposed to a single subcytotoxic stress at $450 \mu \mathrm{M} \mathrm{H}_{2} \mathrm{O}_{2}$ [16] or to five repeated subcytotoxic stresses at $30 \mu \mathrm{M} t$-BHP [11]. Using this criteria too, we can suggest that the UVB stressed HDFs behave like presenescent cells.

Fibronectin, osteonectin and SM22 steady-state mRNA level were all found to be increased in senescent skin HDFs and $72 \mathrm{~h}$ after three or five stresses under UVB, with fibronectin and osteonectin giving the more spectacular results. These three genes, and particularly fibronectin and osteonectin were also found to be expressed in senescent osteoblasts [11], in WI-38 fœtal lung HDFs and in IMR-90 fotal lung HDFs. In $\mathrm{H}_{2} \mathrm{O}_{2}$ - and $t$-BHP-induced SIPS of IMR-90 and WI-38 HDFs, these three genes were also found to be overexpressed in similar extents [10]. This further validates the model of UVB-induced SIPS developed herein.

Fibronectin is known to facilitate the cellular anchorage to culture dishes, thereby decreasing the possibility of apoptosis and explaining in part why senescent cells are resistant to apoptosis. Osteonectin is also a component of the extracellular matrix. Retrovirally-mediated stable overexpression of osteonectin reduces the mitogenic effects of plateletderived growth factor in WI-38 HDFs, which explains partly the sharp decrease of the proliferative potential observed in SIPS [17].

In conclusion, skin HDFs exposed to repeated subcytotoxic doses of UVB present a phenotype of SIPS, which shares many similarities with the fibroblasts obtained in presenescent cultures at $85-90 \%$ of their in vitro replicative life span.

Presenescent and senescent HDFs were shown to promote growth and tumorigenesis of preneoplastic and neoplastic epithelial cells, with greater effects obtained in the senescent cells [12]. HDFs in $\mathrm{H}_{2} \mathrm{O}_{2}$-induced premature senescence also promoted 
growth and tumorigenesis of these cells. According to the results obtained herein, it would be worthwhile studying whether skin HDFs in UVB-induced SIPS have similar promoting effects. Indeed, UVB crosses the epidermis, which contains keratinocytes and melanocytes, and reaches the upper dermis, which contains fibroblasts. It would be also worthwhile to test whether skin HDFs in UVB-induced SIPS promote the growth either of melanocytes and melanoma cells.

The next step is to show that UVB-induced premature senescence exists in vivo, which would not be surprising. Indeed SIPS has already been shown to exist in many pathophysiological conditions. For instance, HDFs excised from gastric veinous ulcers display several features of senescence: reduced proliferative capacity, enlarged size, SA $\beta$-gal activity, overexpression of fibronectin $[18,19]$. HDFs cultured from distal lower extremities in patients with veinous insufficiencies also display cellular characteristics of senescence [20] as well as arteries subjected to balloon angioplasty [21], tissue surrounding liver carcinomas [22] and benign prostatic hyperplasia [23].

\section{Acknowledgements}

O. Toussaint is a Research Associate and F. Chainiaux is a Research Assistant of the FNRS, Belgium. J.-P. Magalhaes thanks FCT, Portugal. We wish to thank the European Union, 5th Framework Programme, Quality of Life, R\&D, 'Protage' (QLK6-CT-1999-02193) and 'Functionage' (QLK6-CT-2001-00310), as well as the Région Wallonne, Belgium Initiative Project 'Modelage'.

\section{References}

[1] M. Serrano, M.A. Blasco, Putting the stress on senescence, Curr. Opin. Cell Biol. 13 (2001) 748-753.

[2] O. Toussaint, E.E. Medrano, T. Von Zglinicki, Cellular and molecular mechanisms of stress-induced premature senescence (SIPS) of human diploid fibroblasts and melanocytes, Exp. Gerontol. 35 (2000) 927-945.

[3] C. Rosette, M. Karin, Ultraviolet light and osmotic stress: activation of the JNK cascade through multiple growth factor and cytokine receptors, Science 274 (1996) 1194-1197.

[4] M. Helenius, L. Makelainen, A. Salminen, Attenuation of NF-kappaB signaling response to UVB light during cellular senescence, Exp. Cell Res. 248 (1999) 194-202.
[5] K. Scharffetter-Kochanek, P. Brenneisen, J. Wenk, G. Herrmann, W. Ma, L. Kuhr, C. Meewes, M. Wlaschek, Photoaging of the skin from phenotypes to mechanisms, Exp. Gerontol. 35 (2000) 307-316.

[6] L. Hayflick, P.S. Moorhead, The serial cultivation of human diploid cell strains, Exp. Cell Res. 25 (1961) 585-621.

[7] O. Lowry, N. Rosebrought, A. Farr, R. Randall, Protein measurement with Folin phenol reagent, J. Biol. Chem. 193 (1951) 265-275.

[8] G.P. Dimri, X. Lee, G. Basile, M. Acosta, G. Scott, C. Roskelley, E.E. Medrano, M. Linskens, I. Rubeli, O. Pereira-Smith, M. Peacoke, J. Campisi, A biomarker that identifies senescent human cells in culture and in aging skin in vivo, Proc. Natl. Acad. Sci. U.S.A. 92 (1995) 9363-9367.

[9] R.D. Ramirez, C.P. Morales, B.S. Herbert, J.M. Rohde, C. Passons, J.W. Shay, W.E. Wright, Putative telomereindependent mechanisms of replicative aging refelect inadequate growth conditions, Genes Dev. 15 (2001) 398-403.

[10] P. Dumont, M. Burton, Q.M. Chen, E.S. Gonos, C. Frippiat, J.B. Mazarati, F. Eliaers, J. Remacle, O. Toussaint, Induction of replicative senescence biomarkers by sublethal oxidative stresses in normal human fibroblast, Free Radical Biol. Med. 28 (2000) 361-373.

[11] E.S. Gonos, A. Derventzy, M. Kveiborg, G. Agiostratidou, M. Kassem, B.F.C. Clark, P.S. Jat, S.I.S. Rattan, Cloning and identification of genes that associate with mammalalian replicative senescence, Exp. Cell Res. 240 (1998) 66-74.

[12] A. Krtolica, S. Parrinello, S. Lockett, P.Y. Desprez, J. Campisi, Senescent fibroblasts promote epithelial cell growth and tumorigenesis: a link between cancer and aging, Proc. Natl. Acad. Sci. U.S.A. 98 (2001) 12072-12077.

[13] H.P. Rodemann, K. Bayreuther, P.I. Francz, K. Dittmann, M. Albiez, Selective enrichment and biochemical characterization of seven human skin fibroblasts cell types in vitro, Exp. Cell Res. 180 (1989) 84-93.

[14] O. Toussaint, D. Lambert, J. Remacle, Mathematical model of the survival curves and of the recovery times for mitosis of cell populations exposed to stresses, In Vitro Toxicol. 9 (1996) 251-259.

[15] C. Frippiat, Q.M. Chen, S. Zdanov, J.P. Magalhaes, J. Remacle, O. Toussaint, Subcytotoxic $\mathrm{H}_{2} \mathrm{O}_{2}$ stress triggers a release of transforming growth factor- $\beta 1$, which induces biomarkers of cellular senescence of human diploid fibroblasts, J. Biol. Chem. 276 (2001) 2531-2537.

[16] Q. Chen, B. Ames, Senescence-like growth arrest induced by hydrogen peroxide in human diploid fibroblast F65 cells, Proc. Natl. Acad. Sci. U.S.A. 91 (1994) 4130-4134.

[17] P. Dumont, F. Chainiaux, F. Eliaers, C. Petropoulou, J. Remacle, C. Koch-Brandt, E.S. Gonos, O. Toussaint, Overexpression of apolipoprotein $\mathrm{J}$ in human fibroblasts protects against cytotoxicity and premature senescence induced by ethanol and tert-butylhydroperoxyde, Cell Stress Chaperones 7 (2002) 23-35.

[18] M.V. Mendez, J.D. Raffetto, T. Phillips, J.O. Menzoian, H.Y. Park, The proliferative capacity of neonatal skin fibroblasts is reduced after exposure to venous ulcer wound fluid: a potential mechanism for senescence in venous ulcers, J. Vasc. Surg. 30 (1999) 734-743. 
[19] M.V. Mendez, A. Stanley, H.Y. Park, K. Shon, T. Phillips, J.O. Menzoian, Fibroblasts cultured from venous ulcers display cellular characteristics of senescence, J. Vasc. Surg. 28 (1998) 876-883.

[20] M.V. Mendez, A. Stanley, T. Phillips, M. Murphy, J.O. Menzoian, H.Y. Park, Fibroblasts cultured from distal lower extremities in patients with venous reflux display cellular characteristics of senescence, J. Vasc. Surg. 28 (1998) 10401050.

[21] M. Fenton, S. Barker, D.J. Kurz, J.D. Erusalimsky, Cellular senescence after single and repeated balloon catheter denudations of rabbit carotid arteries, Arterioscler. Thromb. Vasc. Biol. 21 (2001) 220-226.

[22] V. Paradis, N. Youssef, D. Dargere, N. Ba, F. Bonvoust, J. Deschatrette, P. Bedossa, Replicative senescence in normal liver, chronic hepatitis $\mathrm{C}$, and hepatocellular carcinomas, Hum. Pathol. 32 (2001) 327-332.

[23] J. Choi, I. Shendrik, M. Peacocke, D. Peehl, R. Buttyan, E.F. Ikeguchi, A.E. Katz, M.C. Benson, Expression of senescence-associated beta-galactosidase in enlarged prostates from men with benign prostatic hyperplasia, Urology 56 (2000) 160-166. 